\title{
Pengaruh komposisi media tanam dan waktu aplikasi zat pengatur tumbuh terhadap pertumbuhan dan hasil benih kentang (Solanum tuberosum L.) G2 kultivar medians di dataran medium Jatinangor
}

\section{Effect of growing media compositions and times of growth regulating substances application to growth and yield of the G2 potato seed (Solanum tuberosum $\mathrm{L}$.) cv medians in medium lands of Jatinangor}

Diterima : 24 Mei 2019/Disetujui : 30 Juli 2019 / Dipublikasikan : 7 Agustus 2019

CDepartment of Crop Science, Padjadjaran University

\begin{abstract}
Potatoes are a high-value commercial vegetable that can be used as an alternative food. The low availability of potato seeds affect potato production. The limited area of potatoes in the highlands caused extensification in the medium land is needed through engineering of growing media and growth hormones. It probably can reduce the negative effects of planting potatoes on the medium lands of Jatinangor. The experiment was carried out at the Ciparanje Station, Faculty of Agriculture, Padjadjaran University, Jatinangor. The experiment was using Randomized Block Design with factorial treatment. The first factor was the growing media compositions, while the second factor was the times of growth regulating substances application. The experimental results showed that there was no interaction effect of the growing media compositions and times of growth regulating substances application to growth and yield of the G2 potato seed. Compositions of soil, compost, husk charcoal, and cocopeat (1:1:1:1) showed plant height, leaf area, dry weight, numbers of tubers, and weights of tubers per plant were higher than other treatments. The times of application 20 days after planting (DAP) cytokinin and 40 DAP paclobutrazol suppressed plant height, however it produce numbers and weights of tubers per plant were higher.
\end{abstract}

Keywords: Potatoes · Growing media · Cytokinin - Paclobutrazol • Medium land

\footnotetext{
Dikomunikasikan oleh Sumadi

Hamdani, J.S. • T.P. Dewi • W. Sutari

${ }^{1}$ Staf Pengajar Departemen Budidaya Pertanian, Fakultas Pertanian, Universitas Padjadjaran

${ }^{2}$ Mahasiswa program Studi Agroteknologi Fakultas Pertanian, Universitas Padjadjaran

Korespondensi:
}

Sari. Kentang termasuk jenis sayuran komersial bernilai tinggi yang dapat dijadikan sebagai pangan alternatif. Rendahnya ketersediaan benih kentang dapat berpengaruh terhadap produksi kentang. Terbatasnya lahan penanaman kentang di dataran tinggi sehingga diperlukan ekstensifikasi di dataran medium melalui rekayasa media tumbuh dan hormon tumbuh yang bisa mengurangi efek negatif penanaman kentang di dataran medium. Percobaan ini bertujuan untuk mengetahui interaksi antara komposisi media tanam dengan waktu aplikasi zat pengatur tumbuh terhadap pertumbuhan dan hasil benih kentang G2 kultivar Medians di dataran medium Jatinangor. Percobaan dilaksanakan di Kebun Percobaan Ciparanje, Fakultas Pertanian, Universitas Padjadjaran, Jatinangor. Rancangan percobaan yang digunakan yaitu Rancangan Acak Kelompok Faktorial. Faktor pertama adalah komposisi media tanam dan faktor kedua adalah waktu aplikasi zat pengatur tumbuh sitokinin dan paclobutrazol. Hasil percobaan menunjukkan bahwa tidak terjadi interaksi komposisi media tanam dengan waktu aplikasi zat pengatur tumbuh terhadap pertumbuhan dan hasil benih kentang G2. Komposisi media tanah, kompos, arang sekam, dan cocopeat (perbandingan $\left({ }^{v} v\right)$ 1:1:1:1) menunjukkan tinggi tanaman, luas daun, bobot kering tanaman, jumlah ubi dan bobot ubi per tanaman tertinggi. Waktu aplikasi 20 hari setelah tanam (HST) sitokinin dan 40 HST paclobutrazol dapat menekan tinggi tanaman namun menghasilkan jumlah ubi dan bobot ubi per tanaman tertinggi.

Kata kunci: Kentang $\cdot$ Media $\cdot$ Sitokinin .

Paclobutrazol $\cdot$ Dataran medium 


\section{Pendahuluan}

Kentang (Solanum tuberosum L.) merupakan tanaman hortikultura dengan organ target ubi yang merupakan sumber karbohidrat. Selain itu, kentang mengandung protein, asam amino, mineral, dan vitamin (The International Potato Center, 2008). Kentang termasuk jenis sayuran komersial bernilai tinggi yang dapat digunakan sebagai penunjang program diversifikasi pangan.

\section{Badan Pusat Statistik} mengemukakan bahwa produksi kentang di Indonesia pada tahun 2017 mengalami penurunan sebesar 3,9\% dari tahun 2016. Rendahnya produksi kentang di Indonesia terkait dengan pemakaian benih tidak bermutu, serta pengadaan dan distribusi benih kentang berkualitas belum kontinyu dan memadai. Berdasarkan data Balai Pengembangan Benih Kentang (2017), produksi benih kentang bermutu pada tahun 2015 mencapai 2.000,15 ton dengan kontribusi terhadap kebutuhan benih kentang tingkat nasional sebesar 2,22\% (kebutuhan benih kentang nasional sebesar 90.000 ton/tahun).

Lahan dataran tinggi dengan suhu udara yang sesuai untuk pertanaman kentang di Indonesia masih terbatas. Kegiatan budidaya yang dilakukan terus menerus tidak terkendali dapat menyebabkan erosi dan menurunkan produktivitas tanah. Salah satu alternatif yang dapat diupayakan adalah perluasan penanaman kentang di dataran medium. Pertumbuhan kentang di dataran medium menghadapi kendala terutama suhu tinggi sehingga meningkatkan sintesis giberelin yang dapat menghambat inisiasi ubi. Hal ini menyebabkan ubi yang terbentuk sedikit dan kecil (Tsegaw dan Hammes, 2004).

Komposisi media tanam yang sesuai dengan syarat tumbuh tanaman kentang sangat penting dalam meningkatkan jumlah dan ukuran ubi untuk produksi benih kentang. Tanaman kentang dapat tumbuh baik pada tanah berstruktur remah, gembur, mengandung bahan organik, berdrainase baik, dan memiliki lapisan olah dalam karena produksi tanaman kentang berupa ubi yang berkembang dibawah permukaan tanah. Secara umum, tanah inceptisols seperti yang ada di Jatinangor memiliki kesuburan tanah relatif rendah tetapi dapat diupayakan dengan penanganan dan teknologi yang tepat untuk ditingkatkan (Sudirja et. al., 2007). Media tanam dapat diperbaiki dengan pemberian bahan organik seperti kompos, arang sekam, dan cocopeat.

Faktor lain yang harus diperhatikan dalam meningkatkan produksi benih kentang adalah dengan pemberian Zat Pengatur Tumbuh (ZPT) yang diharapkan dapat mengatur keseimbangan pertumbuhan tanaman menjadi lebih optimal. Menurut Wattimena (1989), tanaman tidak akan menunjukkan respon terhadap zat pengatur tumbuh apabila tidak diberikan pada masa pekanya. Masa peka meliputi waktu pemberian yang disesuaikan dengan stadia pertumbuhan tanaman. Sitokinin merupakan zat pengatur tumbuh yang berperan dalam merangsang pertumbuhan tanaman. Salah satu jenis sitokinin adalah BAP (Benzyl Amino Purine). Menurut Sakya et. al. (2003), selain penggunaan sitokinin, penambahan retardan juga diperlukan untuk menekan aktivitas giberelin. Retardan yang umum digunakan adalah paclobutrazol. Waktu yang tepat saat pemberian paclobutrazol akan efektif menghambat sintesis giberelin sehingga dapat memfokuskan energi untuk pembentukan dan pembesaran ubi.

Maka untuk menghasilkan benih kentang yang bermutu, baik kuantitas maupun kualitas perlu dilakukan percobaan mengenai pengaruh komposisi media tanam dan waktu aplikasi zat pengatur tumbuh terhadap pertumbuhan dan hasil benih tanaman kentang G2 kultivar Medians di dataran medium.

\section{Bahan dan Metode}

Percobaan dilakukan di Rumah Plastik Fakultas Pertanian, Universitas Padjadjaran, Ciparanje, Jatinangor dengan ketinggian $\pm 752 \mathrm{~m}$ di atas permukaan laut (dpl). Waktu percobaan dilaksanakan dari bulan Juli sampai dengan Oktober 2018.

Bahan yang digunakan selama percobaan adalah benih kentang G1 kultivar Medians ukuran S (21-30g), tanah Inseptisol, kompos, arang sekam, cocopeat, sitokinin (BAP), paclobutrazol, polybag ukuran $50 \times 50 \mathrm{~cm}$, pupuk Urea, SP-36, $\mathrm{KCl}$, pestisida dazomet $98 \%$, insektisida profenofos $500 \mathrm{~g} / \mathrm{L}$, bakterisida streptomycin sulfate $6,87 \%$, fungisida mankozeb $64 \%$, dan nematisida karbofuran 3\%. Alat yang digunakan selama percobaan adalah cangkul, 
kored, embrat, ajir, gelas ukur, handsprayer, alat ukur tinggi, termohigrometer, klorofilmeter SPAD, timbangan digital, dan oven.

Rancangan Percobaan menggunakan Rancangan Acak Kelompok (RAK) pola Faktorial yang terdiri atas dua faktor dan tiga ulangan. Faktor pertama adalah kombinasi media tanam (M), yang terdiri dari empat taraf, yaitu: tanah dan kompos dengan perbandingan $\left(\begin{array}{ll}{ }^{v} & v\end{array}\right) 2: 1\left(\mathrm{~m}_{1}\right)$; tanah, kompos, dan arang sekam dengan perbandingan 2:1:1 $\left(\mathrm{m}_{2}\right)$; tanah, kompos, cocopeat, dan arang sekam dengan perbandingan $1: 1: 1: 1\left(\mathrm{~m}_{3}\right)$; dan tanah, kompos, cocopeat, dan arang sekam dengan perbandingan $2: 1: 1: 1\left(\mathrm{~m}_{4}\right)$. Faktor kedua adalah waktu aplikasi zat pengatur tumbuh $(\mathrm{P})$, yang terdiri dari tiga taraf, yaitu $\mathrm{p}_{1}$ (tanpa zat pengatur tumbuh), $\mathrm{p}_{2}$ (20 hari setelah tanam (HST) Sitokinin, 40 HST Paclobutrazol) dan $\mathrm{p}_{3}$ (30 HST Sitokinin, 50 HST Paclobutrazol). Setiap unit percobaan terdiri dari 6 tanaman, sehingga terdapat 216 tanaman percobaan.

Aplikasi sitokinin dan paclobutrazol diberikan dengan konsentrasi 100 ppm pada waktu yang sesuai dengan perlakuan. Cara aplikasi sitokinin dan paclobutrazol adalah dengan menyemprotkan ke bagian atas tanaman (pupus) menggunakan sprayer dengan dosis yang berbeda di setiap stadia tumbuh tanaman. Dosis sitokinin dan paclobutrazol yang diberikan berdasarkan hasil kalibrasi yaitu dengan menyemprotkan ke daun tanaman kentang sampai basah merata.

Perhitungan analisis sifat fisik komposisi media tanam dilakukan sebelum tanam, dengan rumus sebagai berikut:

- $\operatorname{Media}$ density $(\mathrm{kg} / \mathrm{L})=\frac{\text { Media weight }(\mathrm{kg})}{\text { Media volume }(\mathrm{L})}$

- Porosity (\%) $=\frac{\text { Water volume (L) }}{\text { Growing media volume (L) }} \times 100 \%$

- Air space $\%=\frac{\text { Water gravity volume (L) }}{\text { Growing media volume (L) }} \times 100 \%$

- Water retain capacity $(\%)=$ porosity $(\%)$ - Air space $(\%)$

Pengamatan terdiri dari analisis sifat fisik media tanaman, tinggi tanaman, luas daun, bobot kering tanaman, indeks kandungan klorofil, jumlah ubi dan bobot ubi per tanaman, dan persentase ubi kelas benih kelas S, M, dan L. Pengaruh perlakuan diuji dengan uji $\mathrm{F}$ dengan taraf nyata $5 \%$, sedangkan untuk menguji perbedaan nilai rata-rata perlakuan dilakukan dengan uji Duncan pada taraf nyata 5\%.

\section{Hasil dan Pembahasan}

Analisis sifat fisik media tanam. Hasil analisis sifat fisik media tanam pada percobaan dapat dilihat pada Tabel 1. Persentase porositas merupakan proporsi pori total yang terdapat dalam satuan volume media tanam yang diisi air dan udara. Komposisi tanah dan kompos $(2: 1)$ memiliki massa jenis lebih tinggi dengan persentase porositas lebih rendah. Semakin padat media tanam maka semakin rendah porositas suatu media tanam sehingga ketersediaan air pada media tanam berkurang dan semakin sedikit jumlah ruang pori media tanam. Pada kondisi tersebut, dapat menghambat pertumbuhan akibat terhambatnya pertumbuhan akar pada media tanam (Aisyah et. al., 2016). Sedangkan komposisi tanah, kompos, dan arang sekam (2:1:1) memiliki persentase porositas lebih tinggi dikarenakan sifat dari arang sekam yang memiliki porositas tinggi sehingga meningkatkan ruang pori total yang dapat meningkatkan daya serap akar terhadap air dan nutrisi untuk proses fotosintesis.

Komposisi tanah, kompos, arang sekam dan cocopeat (1:1:1:1) serta komposisi tanah, kompos, arang sekam, dan cocopeat $(2: 1: 1: 1)$ memiliki persentase ruang udara dan daya pegang air lebih tinggi. Penambahan cocopeat dan arang sekam dapat memperbaiki sifat tanah inceptisol yang bertekstur liat sehingga menciptakan struktur media tanam yang baik untuk pertumbuhan akar, karena terdapat oksigen yang tersimpan pada media tanam sehingga proses respirasi perakaran tanaman berjalan baik. Adanya penambahan cocopeat yang dapat mempertahankan kelembaban, dan memiliki pori mikro yang mampu menghambat gerakan air lebih besar menyebabkan ketersediaan air lebih tinggi. Hal ini membuat tanaman dapat memiliki pasokan air yang cukup dan dapat mentranslokasikan nutrisi (Irawan dan Kafiar, 2015) untuk proses fotosintesis.

Tinggi Tanaman, Luas Daun, Bobot Kering Tanaman, dan Indeks Kandungan Klorofil. Hasil analisis menunjukkan bahwa tidak terdapat pengaruh interaksi antara komposisi media tanam dan waktu aplikasi zat pengatur tumbuh terhadap tinggi tanaman, luas daun, bobot kering tanaman, dan indeks kandungan klorofil. Namun, secara mandiri 
perlakuan komposisi media tanam berpengaruh nyata pada tinggi tanaman, luas daun, bobot kering tanaman, dan indeks kandungan klorofil, sedangkan perlakuan waktu aplikasi zat pengatur tumbuh berpengaruh nyata pada tinggi tanaman (Tabel 2).

Tabel 2 menunjukkan bahwa komposisi tanah, kompos, cocopeat, dan arang sekam (1:1:1:1) menghasilkan tinggi tanaman, luas daun, dan bobot kering lebih tinggi dibandingkan perlakuan lainnya. Kondisi ini dipengaruhi oleh kebutuhan air, nutrisi dan pertumbuhan akar. Penambahan cocopeat dan arang sekam dapat memperbaiki sifat fisik media tanam sehingga meningkatkan ketersediaan air dan dapat mengikat nutrisi dengan baik bagi tanaman untuk melakukan proses fotosintesis. Zelalem et. al. (2009), dalam Sutari et. al. (2018), menyatakan bahwa ketersediaan nutrisi di dalam media tanam dapat mendukung pertumbuhan tanaman secara optimal yang mempengaruhi pertumbuhan tinggi tanaman.

Agustin et. al. (2014), dalam Sutari et al. (2018), menyatakan bahwa sistem perakaran yang baik akan menunjang pertumbuhan kanopi tanaman dengan menyediakan air dan nutrisi. dari media tanam untuk fotosintesis, sedangkan kanopi tanaman menyediakan fotosintat untuk pertumbuhan akar dan bagian tanaman lainnya.

Tabel 1. Hasil analisis sifat fisik media tanam.

\begin{tabular}{ccccc}
\hline Perlakuan & $\begin{array}{c}\text { Massa Jenis } \\
\mathbf{( k g / \mathbf { L } )}\end{array}$ & $\begin{array}{c}\text { Persentase } \\
\text { Porositas (\%) }\end{array}$ & $\begin{array}{c}\text { Persentase Ruang } \\
\text { Udara (\%) }\end{array}$ & $\begin{array}{c}\text { Persentase Daya Pegang } \\
\text { Air (\%) }\end{array}$ \\
\hline $\mathrm{m}_{1}$ & 0,91 & 41,00 & 5,00 & 30,00 \\
$\mathrm{~m}_{2}$ & 0,80 & 52,25 & 8,00 & 36,50 \\
$\mathrm{~m}_{3}$ & 0,68 & 48,65 & 11,00 & 41,50 \\
$\mathrm{~m}_{4}$ & 0,72 & 44,50 & 10,75 & 43,65 \\
\hline
\end{tabular}

Tabel 2. Pengaruh komposisi media tanam dan waktu aplikasi zat pengatur tumbuh terhadap tinggi tanaman, luas daun, bobot kering tanaman, dan indeks kandungan klorofil.

\begin{tabular}{ccccc}
\hline Perlakuan & $\begin{array}{c}\text { Tinggi Tanaman } 8 \\
\text { MST (cm) }\end{array}$ & Luas Daun $\left.\mathbf{( c m}^{2}\right)$ & $\begin{array}{c}\text { Bobot Kering } \\
\text { Tanaman } \mathbf{( g r})\end{array}$ & $\begin{array}{c}\text { Indeks Kandungan } \\
\text { Klorofil }\end{array}$ \\
\hline Komposisi Media Tanam (M) & & & $29,70 \mathrm{~b}$ \\
$\mathrm{~m}_{1}$ & $63,76 \mathrm{a}$ & $5546,40 \mathrm{a}$ & $23,59 \mathrm{a}$ & $29,11 \mathrm{~b}$ \\
$\mathrm{~m}_{2}$ & $73,65 \mathrm{~b}$ & $8015,27 \mathrm{~b}$ & $31,95 \mathrm{~b}$ & $25,41 \mathrm{a}$ \\
$\mathrm{m}_{3}$ & $79,26 \mathrm{~b}$ & $8638,01 \mathrm{~b}$ & $36,89 \mathrm{~b}$ & $26,93 \mathrm{ab}$ \\
$\mathrm{m}_{4}$ & $73,52 \mathrm{~b}$ & $7667,12 \mathrm{~b}$ & $31,43 \mathrm{~b}$ & $27,67 \mathrm{a}$ \\
\hline Waktu Aplikasi Zat Pengatur Tumbuh (P) & & & $28,26 \mathrm{a}$ \\
$\mathrm{p}_{1}$ & $80,08 \mathrm{c}$ & $7502,90 \mathrm{a}$ & $31,97 \mathrm{a}$ & $27,43 \mathrm{a}$ \\
\hline $\mathrm{p}_{2}$ & $65,15 \mathrm{a}$ & $7283,14 \mathrm{a}$ & $28,67 \mathrm{a}$ & $32,25 \mathrm{a}$ \\
\hline
\end{tabular}

Keterangan : Angka yang ditandai dengan huruf berbeda menyatakan berbeda nyata menurut Uji Jarak Berganda Duncan pada taraf $5 \%$.

Tabel 3. Pengaruh komposisi media tanam dan waktu aplikasi zat pengatur tumbuh terhadap jumlah ubi, bobot ubi, dan persentase ubi benih kelas kualitas.

\begin{tabular}{|c|c|c|c|c|c|}
\hline \multirow{2}{*}{ Perlakuan } & \multirow{2}{*}{$\begin{array}{c}\text { Jumlah ubi } \\
\text { (knol) }\end{array}$} & \multirow{2}{*}{ Bobot ubi (g) } & \multicolumn{3}{|c|}{ Persentase Ubi Benih Kelas Kualitas } \\
\hline & & & $\mathrm{S}(\%)$ & M (\%) & L (\%) \\
\hline \multicolumn{6}{|c|}{ Komposisi Media Tanam (M) } \\
\hline $\mathrm{m}_{1}$ & $7,55 \mathrm{a}$ & $146,53 \mathrm{a}$ & $97,70 \mathrm{~b}$ & $2,29 \mathrm{a}$ & 0,00 \\
\hline $\mathrm{m}_{2}$ & $9,83 \mathrm{ab}$ & $159,28 \mathrm{ab}$ & $96,06 \mathrm{~b}$ & $3,93 \mathrm{a}$ & 0,00 \\
\hline $\mathrm{m}_{3}$ & $10,55 \mathrm{~b}$ & $185,98 \mathrm{bc}$ & $94,28 \mathrm{~b}$ & $5,72 \mathrm{a}$ & 0,00 \\
\hline $\mathrm{m}_{4}$ & $9,42 \mathrm{ab}$ & $202,36 \mathrm{c}$ & 87,98 a & $12,01 \mathrm{~b}$ & 0,00 \\
\hline \multicolumn{6}{|c|}{ Waktu Aplikasi Zat Pengatur Tumbuh (P) } \\
\hline $\mathrm{p}_{1}$ & $9,42 \mathrm{ab}$ & $156,04 \mathrm{a}$ & $94,73 \mathrm{a}$ & $5,27 \mathrm{a}$ & 0,00 \\
\hline $\mathrm{p}_{2}$ & $10,54 \mathrm{~b}$ & $191,70 \mathrm{~b}$ & $94,45 \mathrm{a}$ & $5,54 \mathrm{a}$ & 0,00 \\
\hline $\mathrm{p}_{3}$ & $8,06 \mathrm{a}$ & $172,87 \mathrm{ab}$ & $92,84 \mathrm{a}$ & $7,15 \mathrm{a}$ & 0,00 \\
\hline
\end{tabular}

Keterangan : Angka yang ditandai dengan huruf berbeda menyatakan berbeda nyata menurut Uji Jarak Berganda Duncan pada taraf $5 \%$. 
Komposisi media tanah, kompos, cocopeat, dan arang sekam = 1:1:1:1) menghasilkan indeks kandungan klorofil lebih rendah dibandingkan perlakuan lainnya tetapi tidak berbeda nyata dengan komposisi media tanah, kompos, cocopeat, dan arang sekam $(2: 1: 1: 1)$. Rendahnya indeks kandungan klorofil berhubungan dengan luas daun. Struktur media tanam yang dihasilkan dengan penambahan arang sekam dan cocopeat memacu proses pembelahan dan pemanjangan sel pada organ tumbuhan, salah satunya pada pertumbuhan luas daun. Sesuai dengan pendapat Musyarofah et. al. (2006), bahwa kandungan klorofil juga dipengaruhi struktur morfologi dan anatomi dari suatu tanaman. Menurut Musyarofah et. al. (2006), semakin tua umur daun maka kemampuan untuk berfotosintesis semakin berkurang sehingga menyebabkan kerusakan pada klorofil karena fungsinya tidak berjalan dengan baik walaupun luas daunnya meningkat.

Waktu aplikasi 20 HST sitokinin dan 40 HST paclobutrazol menghasilkan tinggi tanaman lebih rendah. Aplikasi paclobutrazol yang lebih awal dapat menghambat aktivitas sintesis giberelin (GA). Penghambatan GA menyebabkan sel tanaman terus membelah tetapi sel-sel baru tidak mengalami pemanjangan sehingga terbentuk cabang dengan panjang buku lebih pendek (Chaney et. al., 2005) mengakibatkan tinggi tanaman yang lebih pendek. Sejalan dengan hasil penelitian Hamdani et. al. (2018), bahwa aplikasi paclobutrazol 30 HST menghasilkan tinggi tanaman lebih pendek dibandingkan aplikasi paclobutrazol 45 HST pada tanaman kentang. Aplikasi paclobutrazol lebih awal pada stadia pertumbuhan maka daya hambatnya akan lebih tinggi.

Jumlah Ubi, Bobot Ubi dan Persentase Ubi kelas Benih. Hasil analisis menunjukkan bahwa tidak terdapat pengaruh interaksi antara komposisi media tanam dan waktu aplikasi zat pengatur tumbuh terhadap tinggi tanaman, luas daun, bobot kering tanaman, dan indeks kandungan klorofil. Namun, secara mandiri perlakuan

Komposisi media tanam berpengaruh nyata pada jumlah ubi, bobot ubi dan persentase ubi kelas benih, sedangkan perlakuan waktu aplikasi zat pengatur tumbuh berpengaruh nyata pada jumlah ubi dan bobot ubi (Tabel 3). Komposisi media tanah, kompos, cocopeat, dan arang sekam (1:1:1:1) menghasilkan jumlah ubi dan bobot ubi tertinggi. Komposisi media tanah, kompos, cocopeat, dan arang sekam $(1: 1: 1: 1)$ memiliki persentase ruang udara dan persentase daya pegang air yang tinggi sehingga tata air dan tata udara media tanam baik untuk pertumbuhan dan perkembangan akar dan stolon. Sesuai dengan pendapat Andri et. al. (2016), dalam Sutari et al. (2018), bahwa penambahan $50 \mathrm{~g}$ kompos dari tandan sawit dan $50 \mathrm{~g}$ cocopeat per tanaman dapat memperbaiki sifat kimia dan fisika tanah karena meningkatkan ketersediaan nutrisi dan serapan nutrisi oleh akar, memperbaiki struktur tanah dan aerasi tanah.

Asandhi dan Gunadi (2006) mengemukakan bahwa jumlah ubi kentang ditentukan oleh jumlah stolon yang terbentuk dan dipengaruhi oleh penyerapan air dan nutrisi dari dalam media tanam untuk proses fotosintesis. Besarnya fotosintat yang dialirkan dan disimpan sebagai cadangan makanan menentukan bobot ubi karena ubi sebagai tempat cadangan makanan hasil proses fotosintesis. Peningkatan pembentukan dan pengisian ubi menghasilkan jumlah ubi yang banyak dengan ukuran yang besar (Sutater et. al., 1993).

Komposisi media tanah, kompos, cocopeat, dan arang sekam (2:1:1:1) memiliki persentase ubi benih G2 kelas $S$ lebih rendah namun memiliki persentase ubi benih G2 kelas M lebih tinggi dibandingkan perlakuan lainnya. Komposisi media tanah, kompos, cocopeat, dan arang sekam (2:1:1:1) mendukung perbaikan struktur tanah dengan berstruktur remah, gembur, mengandung bahan organik, memiliki drainase dan aerasi yang baik sehingga sesuai dengan media tanam yang baik untuk pertumbuhan dan perkembangan ubi kentang.

Waktu aplikasi 20 HST sitokinin dan 40 HST paclobutrazol menghasilkan jumlah dan bobot ubi tertinggi. Sejalan dengan hasil penelitian Salsabila (2017) menunjukkan bahwa aplikasi 30 HST Sitokinin dan 40 HST Paclobutrazol menghasilkan jumlah ubi lebih tinggi dengan rata-rata sebesar 17,33 knol pada tanaman kentang. Menurut Frommer dan Sonnewald (1995) dalam Tekalign and Hammes (2005) persaingan antar inisiasi ubi dapat menurunkan jumlah ubi yang terbentuk, tetapi hal itu juga tergantung pada waktu pemberian paklobutrazol dan kondisi tempat penanaman. Aplikasi sitokinin lebih awal pada tanaman 
kentang memacu pembelahan sel dan pembentukan organ, dan meningkatkan aktivitas wadah penampung hara sehingga saat diberi paclobutrazol, fotosintat dialirkan untuk meningkatkan pembentukan dan pembesaran ubi kentang.

Kombinasi yang tepat pada pemberian zat pengatur tumbuh mampu menghasilkan bobot ubi yang lebih besar (Wattimena, 1995). Menurut Tekalign dan Hammes (2005) bahwa aplikasi paclobutrazol pada fase awal pembentukan ubi lebih efektif menekan giberelin dibandingkan aplikasi pada akhir fase pembentukan ubi. Hamdani et. al. (2017) menambahkan bahwa waktu aplikasi paclobutrazol sangat penting dilakukan pada awal fase pembentukan ubi (30 HST) karena dapat menyebabkan penurunan pertumbuhan tunas tetapi dapat meningkatkan pembentukan ubi karena peningkatan asimilat yang dialihkan pada proses pembentukan ubi.

Komposisi media tanam dan waktu aplikasi zat pengatur tumbuh menghasilkan persentase ubi benih G2 kelas $S$ memiliki persentase yang lebih tinggi dibandingkan kelas $\mathrm{M}$ dan L. Tingginya persentase ubi benih G2 kelas S pada penanaman kentang dengan tujuan untuk produksi benih akan sesuai dengan permintaan pasar. Sejalan dengan hasil penelitian Adiyoga et. al. (2014), bahwa petani responden lebih menyukai ubi berukuran $30-40 \mathrm{~g}$ yang termasuk ke dalam ubi benih G2 kelas $S$ karena memiliki bobot dan ukuran yang lebih kecil sehingga mudah untuk disimpan, dan didistribusikan

\section{Kesimpulan}

Dari hasil percobaan dan pembahasan dapat disimpulkan bahwa:

1. Tidak terdapat pengaruh interaksi antara komposisi media tanam dan waktu aplikasi zat pengatur tumbuh terhadap pertumbuhan dan hasil benih kentang G2 kultivar Medians di dataran medium Jatinangor.

2. Komposisi media tanah : kompos : arang sekam : cocopeat $(1: 1: 1: 1)$ memberikan nilai lebih tinggi terhadap tinggi tanaman, luas daun, bobot kering tanaman, jumlah ubi dan bobot ubi per tanaman.

3. Aplikasi 20 HST sitokinin dan 40 HST paclobutrazol menyebabkan tinggi tanaman lebih rendah tetapi menghasilkan jumlah ubi dan bobot ubi yang lebih tinggi.

\section{Ucapan Terima Kasih}

Terimakasih kepada Direktorat Jendral Pendidikan Tinggi Kementrian Riset dan Teknologi, melalui Hibah Kompetensi Tahun Anggran 2018 berdasarkan surat keputusan Nomor 01/E/KPT/2018 dan perjanjian/ Kontrak No 124/SP2H/PTNBH/DRPM/2018

\section{Daftar Pustaka}

Adiyoga, Suwandi, W., dan Kartasih,A. 2014. Sikap petani terhadap pilihan atribut benih dan varietas kentang. Balai Penelitian Tanaman Sayuran. J. Hort 24 (1) : 76-84.

Aisyah, D.S., Kurniatin, T., dan Maryam, S. 2006. Kesuburan Tanah dan Pemupukan. Jurusan Ilmu Tanah, Faperta Unpad : Bandung. Hlm : 7 - 18

Asandhi, A.A., dan Gunadi, N. 2006. Syarat Tumbuh Tanaman Kentang. Buku Tahunan Hortikultura, Seri : Tanaman Sayuran. Direktorat Jenderal Tanaman Pangan dan Hortikultura. Jakarta.

Azima, N.S., Nuraini, A., Sumadi dan Hamdani,J.S.,.2017.Respons pertumbuh- an dan hasil benih kentang G0 di datar- an medium terhadap waktu dan cara aplikasi paclobutrazol. Jurnal Kultivasi 16(2) : 313 319.

Badan Pusat Statistik. 2017. Produksi Kentang Menurut Provinsi 2016-2017. Available at http://www.bps.go.id/ (Diakses pada 2 Juli 2018).

Balai Pengembangan Benih Kentang. 2017. Profil Balai Pengembangan Benih Kentang Pangalengan. Dinas Tanaman Pangan dan Hortikultura Provinsi Jawa Barat.

Chaney, William R. 2005. A Paclobutrazol Treatment Can Leave a Tree More Stress Tolerant. Reprinted from Golfdom solution ideas and opinion. Advanstar publication. U.S.A.

Hamdani, J.S., Nuraini, A., Sumadi, and Mubarok, S. 2018. Effects of application time and concentration of paclobutrazol on the growth and yield of potato seed ofG2 cultivar medians at medium altitude. J. Agron 17 (3) : 169 - 173.

Irawan, A., dan Kafiar, Y. 2015. Pemanfaatan Cocopeat dan Arang Sekam Padi sebagai 
Media Tanam Bibit Cempaka Waisan (Elmerrilia ovalis). Prosiding Seminar Nasional Masy Biodiv Indon, 1 (4) : 805808.

Musyarofah, N., Susanto, S.A., dan Kartosoewarno, S. 2006. Respon tanaman pegagan (Centella asiatica L.) terhadap pemberian pupuk alami di bawah naungan. Seminar Sekolah Pasca Sarjana. Institut Pertanian Bogor. Bogor.

Salsabila, P. N. 2017. Pengaruh Waktu Aplikasi Sitokinin dan Paclobutrazol terhadap Pertumbuhan dan Hasil Benih Kentang G2 (Solanum tuberosum L.) Kultivar Medians di Dataran Medium Jatinangor. Skripsi. Fakultas Pertanian, Universitas Padjadjaran, Jatinangor

Sakya, A.T., A. Yunus, Samanhudi, dan U. Baroroh. 2003. Pengaruh coumarin dan aspirin dalam menginduksi umbi mikro kentang (Solanum tuberosum L.). Jurnal Agrosains, 5 (1) : 20-4.

Sudirja, R., M. A. Sholihin, dan S. Rosniawaty. 2007. Respons Beberapa Sifat Kimia Inceptisols asal Rajamandala dan Hasil Bibit Kakao (Theobroma cacaoL.) melalui Pemberian Pupuk Organik dan Pupuk Hayati. Universitas Padjadjaran.

Sutari, W., Sumadi., Nuraini, A., and Hamdani, J.S. 2018. Growing media compositions and watering intervals on seed production of potatoes G2grown at medium altitude. Asian J. Crop Sci 10 (4) : 190 - 197.

The International Potato Center.2008. Facts And Figures: 2008 - The International Year Of The Potato. Cip. Available at http://www.potato.org (Diakses pada 5 Februari 2018

Tekalign,T. and P.S Hammes. 2005. Growth Responses of potato (Solanum tuberosum L.) grown in a hot tropical lowland to applied paclobutrazol : 1 . shoot attributes, assimilate production and allocation. New Zealand J. of Crop and Hort. Sci. 33 (1) : 35 -42 .

Tsegaw, T and P.S. Hammes. 2004. Growth responses of potato (Solanum tuberosum L.) grown in a hot tropical lowland to applied paclobutrazol : 1 . shoot attributes, assimilate production and allocation, 2 . tuber attributes. New Zealand J. of Crop and Hort. Sci. 33 : 35-51.

Sutater, T., Asandhi A.A., dan Hermanto. 1993. Pengaruh Ukuran Ubi dan Jarak Tanam terhadap Produksi Ubi Mini Kentang kultivar Knebbec. Bul. Penel. Horti. 22 (2) : $12-18$.

Wattimena, G.A. 1989. Zat Pengatur Tumbuh. Institut Pertanian Bogor, Bogor.

Wattimena, G.A. 1995. Pengembangan Propagul Kentang Unggul dan Bermutu. Fakultas Pertanian. Bogor. Hal 1 - 7. 